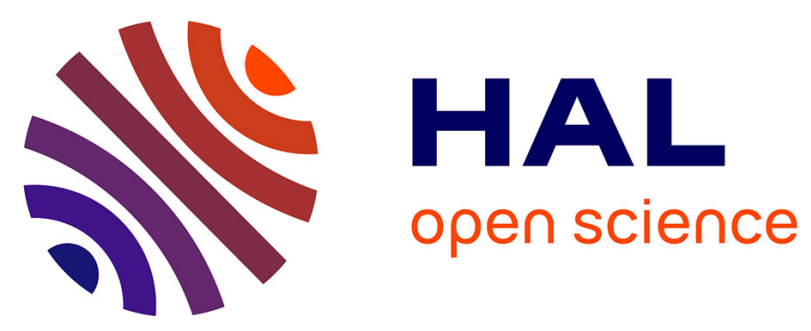

\title{
Fasting Urinary Osmolality, CKD Progression, and Mortality: A Prospective Observational Study
} Nahid Tabibzadeh, Sandra Wagner, Marie Metzger, Martin Flamant, Pascal Houillier, Jean-Jacques Boffa, François Vrtovsnik, Eric Thervet, Bénédicte Stengel, Jean-Philippe Haymann

\section{To cite this version:}

Nahid Tabibzadeh, Sandra Wagner, Marie Metzger, Martin Flamant, Pascal Houillier, et al.. Fasting Urinary Osmolality, CKD Progression, and Mortality: A Prospective Observational Study. American Journal of Kidney Diseases, 2019, 73 (5), pp.596-604. 10.1053/j.ajkd.2018.12.024 . hal-02380902

\section{HAL Id: hal-02380902 https://hal.science/hal-02380902}

Submitted on 22 Oct 2021

HAL is a multi-disciplinary open access archive for the deposit and dissemination of scientific research documents, whether they are published or not. The documents may come from teaching and research institutions in France or abroad, or from public or private research centers.
L'archive ouverte pluridisciplinaire HAL, est destinée au dépôt et à la diffusion de documents scientifiques de niveau recherche, publiés ou non, émanant des établissements d'enseignement et de recherche français ou étrangers, des laboratoires publics ou privés.

\section{(c) (1) $\$$}

Distributed under a Creative Commons Attribution - NonCommerciall 4.0 International 


\section{Fasting Urinary Osmolality and CKD Progression: A Prospective Observational}

\section{Study}

Nahid Tabibzadeh ${ }^{1,2 *}$, M.D., Ph.D. Sandra Wagner ${ }^{3,4 *}$, Ph.D., Marie Metzger ${ }^{4}$, Ph.D., Martin Flamant ${ }^{5,6}$, M.D., Ph.D., Pascal Houillier ${ }^{7,8}$, M.D., Ph.D., Jean-Jacques Boffa ${ }^{1,2,9}$, M.D., Ph.D., Francois Vrtovsnik ${ }^{5,10}$, M.D., Ph.D., Eric Thervet ${ }^{7,11}$, M.D., Ph.D., Bénédicte Stengel ${ }^{3,4}$, M.D., Ph.D., Jean-Philippe Haymann ${ }^{1,2}$, M.D., Ph.D., on behalf of the NephroTest Study Group

*NT and SW equally contributed to this work.

${ }^{1}$ Sorbonne Université, Inserm UMR_S 1155, Paris, France

${ }^{2}$ Unit of Renal Physiology, AP-HP Hôpital Tenon, Paris, France

${ }^{3}$ CESP, Inserm U1018, Univ Paris-Saclay, Univ Paris-Sud, UVSQ, Villejuif, France

${ }^{4}$ FCRIN INI-CRCT, France

${ }^{5}$ Université Paris Diderot, Paris, France

${ }^{6}$ Unit of Renal Physiology, AP-HP Hôpital Bichat, Paris, France

${ }^{7}$ Université Paris Descartes, Paris, France

${ }^{8}$ Unit of Renal Physiology, AP-HP Hôpital Européen Georges Pompidou, Paris, France

${ }^{9}$ Unit of Nephrology, AP-HP Hôpital Tenon, Paris, France

${ }^{10}$ Unit of Nephrology, AP-HP Hôpital Bichat, Paris, France

${ }^{11}$ Unit of Nephrology, AP-HP Hôpital Européen Georges Pompidou, Paris, France Corresponding author:

Bénédicte Stengel

CESP, Inserm U1018

16 avenue P. Vaillant Couturier 
F-94807 Villejuif cedex 


\section{Abstract}

Rationale \& Objective. Chronic kidney disease (CKD) characterized by decreased glomerular filtration rate (GFR) is often accompanied by various degrees of impaired tubular function in the cortex and medulla. Assessment of tubular function may, therefore, be useful in establishing the severity of kidney disease and in identifying those at greater risk of $\mathrm{CKD}$ progression. We explored reductions in urinary concentrating ability, a well-known feature of CKD, as a risk factor for GFR decline and end-stage kidney disease (ESRD).

Study Design. Prospective longitudinal cohort study.

Setting and participants. 2,084 adult patients with CKD stages 1 to 4 from the French NephroTest Cohort Study.

Predictor. Fasting urinary osmolality (Uosm) measured by delta cryoscopy.

Outcomes. End-stage renal disease (ESRD), mortality prior to ESRD, and measured GFR (mGFR) assessed by ${ }^{51} \mathrm{Cr}$ - EDTA renal clearance.

Analytical Approach. Cause-specific hazards models were fit to estimate crude and adjusted associations of urinary osmolality with ESRD and death prior to ESRD. Linear mixed models with random intercepts were fit to evaluate the association of urinary osmolality with slope of decline in mGFR.

Results. At baseline, mean age was 58.7 \pm 15.2 (SD) years with a median mGFR of 40.2 [IQR, 29.1-54.5] ml/min and a median fasting Uosm of $502.7 \pm 151.7 \mathrm{mOsm} / \mathrm{kg} \mathrm{H}_{2} \mathrm{O}$. Baseline fasting Uosm was strongly associated with mGFR $(\mathrm{R}=0.54, \mathrm{p}<0.001) .380$ ESRD events and 225 deaths prior to ESRD occurred during a median follow-up of 5.9 years [3.8-8.2]. Patients with lower baseline fasting Uosm had a higher adjusted risk of 
ESRD but not of mortality (HRs of 1.9 [95\% CI, 1.2-3.0] and 0.99 [95\% CI, 0.68-1.44], respectively, for the lowest versus highest tertile). Based on a mixed linear model, adjusted for baseline mGFR and clinical characteristics, patients in the lowest tertile of baseline Uosm had a steeper decline in kidney function $(-4.9 \% \pm 0.9 \%$ per year, $\mathrm{p}<0.001)$ compared to patients in the highest tertile.

Limitations. Fasting was self-reported.

Conclusions. Fasting Uosm may be a useful tool, in addition to GFR and albuminuria, for assessing non-glomerular damage in patients with CKD who are at higher risk of CKD progression.

Keywords: urine osmolality, chronic kidney disease (CKD), CKD progression, tubular damage; urine concentration ability, glomerular filtration rate (GFR), measured GFR (mGFR), GFR decline, end-stage renal disease (ESRD), prognostic factor, biomarker 


\section{Introduction}

The ability of kidneys to concentrate urine enables the excretion of a maximal amount of osmoles in a minimal urine volume, leading to a urinary osmolality which can considerably exceed plasma osmolality. Differences among species depend on the axial length of the papilla, and human kidneys are able to raise urine osmolality to a maximum of $1200 \mathrm{mOsm} / \mathrm{kg} \mathrm{H} \mathrm{H}_{2} \mathrm{O}$ after a fasting state. ${ }^{1}$

Chronic kidney disease (CKD) is characterized by a decreased glomerular filtration rate (GFR) and several tubular defects including impaired urine concentration ability, especially at late stages of the kidney disease. Of note, regardless of the cause of Kidney failure, the natural history of chronic kidney failure is characterized by hyposthenuria in experimental models as well as in humans ${ }^{2-4}$.

It is not currently known whether therapeutic interventions on urine concentration are efficient in preventing kidney function decline. Some authors suggest that decreasing urine osmolality, and consequently plasma vasopressin, would be kidney protective, ${ }^{5-8}$ whereas others conclude that high water intake and high urine volume output could be deleterious $^{3,9-11}$.

Kidney function is usually assessed by the estimation or the measure of the GFR i.e. the filtration process within glomeruli, whereas nephron functions also include other structures such as tubules and peritubular capillaries. Indeed, tubules ensure several other functions, including the establishment and maintenance of a cortico-papillary concentration gradient. Moreover, many studies have shown the highly predictive value of interstitial fibrosis and tubular atrophy in CKD, irrespective of the underlying nephropathy, either in the native kidney or in allografts ${ }^{12-16}$. We presumed that fasting 
urine osmolality, a reliable marker of maximal urine concentration, would provide a relevant assessment of tubular dysfunction independently of glomerular alteration and thus could be of prognostic value. Using a prospective cohort of stage 1-4 CKD patients, our study aimed at investigating the association of fasting urine osmolality with CKD progression (i.e. end stage renal disease (ESRD) and mGFR decline and pre-ESRD death. We hypothesized that lower fasting urine osmolality would be associated with worse outcomes.

\section{Methods}

\section{Study population and design}

The NephroTest cohort is a prospective multicenter study that enrolled 2,084 adult patients with all stages of CKD referred by nephrologists to three departments of physiology for extensive workups between January 2000 and December $2012{ }^{17}$. Patients were recruited and followed-up during this period until December 2013. Eligible patients were $\geq 18$ years of age at inclusion and had neither started dialysis nor received a kidney transplant. Pregnant women were excluded. After exclusion of 62 patients with missing data for urine osmolality measurement, 123 patients with $\mathrm{mGFR}<15 \mathrm{ml} / \mathrm{min}$ and 103 patients with a single visit and untraceable thereafter through any clinical or administrative health databases, this analysis included 1,796 patients (Figure 1). All patients provided written informed consent. The NephroTest study design was approved by an ethics committee (CCTIRS MG/CP09.503).

\section{Data collection and measurements}

Over the study period, patients underwent a total of 5199 laboratory visits with Uosm and mGFR data and a median of 2 [IQR, 1-4] visits in addition to the inclusion 
visit. The median period between visits was 1.08 (IQR, 0.99-1.51) years.

During a 5-h in-person visit, a large set of clinical and laboratory data were collected. They included demographics, renal diagnosis, medical history, height and weight, blood pressure (BP), and treatments received. Height and weight were measured at the clinical examination and obesity was defined as body mass index $>30 \mathrm{~kg} / \mathrm{m}^{2}$. Diabetes was either self-reported or defined as fasting glycemia $>7 \mathrm{mmol} / \mathrm{L}$ or antidiabetic drug treatment. Smoking was self-reported. Hypertension was defined as elevated blood pressure (BP, average of 3 office measurements) $\geq 140 / 90 \mathrm{mmHg}$ or the use of antihypertensive drugs. Cardiovascular disease history was defined as a history of stroke, ischemic heart disease (angioplasty, surgical coronary bypass, or myocardial infarction), or heart failure. The type of nephropathy was collected from patient's medical record. Patients were instructed to fast (not to eat or drink) from 8 p.m. the day before the admission. At each visit, fasting blood samples, 24-h urine collection and fasting urine samples were collected. Fasting Uosm was measured by delta cryoscopy (Osmometer, Radiometer, Denmark). Though the terms osmolality (osmoles per kilogram of solute) and osmolarity (osmoles per liter of solvent) differ scientifically, for the sake of simplicity, in this article Uosm refers to both. Urinary albumin-creatinine ratio (ACR) was measured in $81 \%$ of the patients, either using the 24 -hour collection or a spot morning sample, and estimated from the protein-creatinine ratio (PCR) in $17 \%$ of those without urinary tract infection; it was missing in others.

At each visit, mGFR was measured by urinary ${ }^{51}$ Cr-EDTA clearance (GE Healthcare, Velizy, France) and determined as the average of 5-7 consecutive $30 \mathrm{~min}$ clearance periods (fractionated clearances), as previously described ${ }^{18}$. 


\section{Outcomes}

The primary end-point of this study was ESRD defined as initiation of renal replacement therapy (RRT) by dialysis or pre-emptive transplantation as well as its competitive event of pre-ESRD death. The secondary end-point was mGFR over time. Information about deaths and their causes and ESRD events was obtained either from patient medical records or linkage with the national death registry and the national REIN (Renal Epidemiology and Information Network) registry of treated ESRD. All survival data were right-censored on 31 December 2013, or on the last visit when the patients were not found in registries.

\section{Statistical analyses}

Univariate analyses were performed with all the covariates, and all variables with $\mathrm{p}<0.2$ were included on the multivariable analysis. Patient characteristics were then described according to gender-specific tertiles of Uosm.

First, differences between the three tertiles were tested with analysis of variance (ANOVA), the Kruskal-Wallis test or the Chi-square test, as appropriate.

Second, we performed cause-specific hazards models to estimate crude and adjusted hazard ratios (HRs) and 95\% confidence intervals [HR (95\% CI)] for ESRD and pre-ESRD death associated with gender-specific Uosm tertiles, using the highest tertile as the reference category. In each model, the competing events were treated as censored observations. The cause-specific approach is the most suitable to account for competing risks of concurrent events for etiological studies according to previous studies ${ }^{19}$. Sequential models were developed for each outcome studied with similar covariates for adjustment in both analyses: model 1 was adjusted for mGFR; model 2 included model 1 
covariates and age, sex, center, ethnicity, obesity; model 3 included model 2 covariates and ACR in class $(<3,3-30,>30 \mathrm{mg} / \mathrm{mmol})$, high blood pressure, diabetes, CV history, smoking status, ACE inhibitors or ARBs, nephropathy type, and natremia. We also tested the interaction between osmolality and type of nephropathy; and between osmolality and age. In all models, we performed tests for linear trend across tertiles of Uosm. Subsidiary analysis was performed with Uosm treated as a continuous variable. Assessment of the Schoenfeld residuals showed that none of the variables (except mGFR) violated the proportional-hazards assumption in the cause-specific hazards model for ESRD. Consequently, interaction term between mGFR and $\log ($ time) was used in model 1 to 3 for ESRD to account for time-varying effects.

Third, we used linear mixed model with random intercepts and slope to estimate mean annual decline in mGFR and study the association between baseline osmolality and mGFR in terms of mGFR slope where slope is reported in \% per year. We estimated mean differences in mGFR slopes and 95\% confidence interval adjusted for baseline mGFR group $(<30,30-45,>45 \mathrm{~mL} / \mathrm{min})$, as well as for the following covariates: fasting urine osmolarity, age, gender, center, ethnicity, $\log (\mathrm{PCR})$, elevated blood pressure, $\mathrm{BMI}$, CV history, diabetes, smoking, ACE inhibitor or ARB intake. The covariance matrix for the random effects was estimated for each group of baseline mGFR separately (using group option in random statement from proc mixed (SAS 9.3), and robust sandwich variance estimators were used to estimate variances of regression coefficients.

Interactions with time were tested for all covariates. Only the interaction terms that were statistically significant according to the Wald test and improved the model according to the Akaike information criteria (AIC) were included in the final model. Missing values 
accounted for less than 3\% of most variables used in our multivariable analyses and were replaced by median or mode, except for ethnicity and ACR for which we used a missing data class. Finally, in a sensitivity analysis, we included the 62 patients with missing data for urine osmolality measurement. Multiple imputations of our dataset were performed using all covariates of the multivariable models ( $\mathrm{n}=5$ imputed dataset, Fully Conditional Specification using all covariates including outcomes, maximum 20 iterations), causespecific hazards models were fitted on each complete dataset and finally the estimated HRs were combined using Rubin's rules ${ }^{20}$.

A two-sided P-value $<0.05$ indicated statistical significance. Data analyses were performed with SAS software, version 9.3 (SAS institute, Cary, NC) and with R version 3.0.2 software (R Development Core Team, 2005).

\section{Results}

Mean age at baseline was $58.7 \pm 15.2$ years, $67.7 \%$ were male, $21.3 \%$ had obesity $\left(\mathrm{BMI} \geq 30 \mathrm{~kg} / \mathrm{m}^{2}\right)$, and $27.3 \%$ had diabetes (Table 1). Diabetic nephropathy was present in $10.1 \%$, vascular in $26.6 \%$, glomerular in $14.5 \%$, interstitial in $9.2 \%$, and polycystic kidney disease in $5.8 \%$. In terms of serum sodium level, $65.2 \%$ of patients were in the reference range (138 to $142 \mathrm{mmol} / \mathrm{L}$ ), while $18.1 \%$ had hyponatremia and $16.7 \%$ hypernatremia. Median mGFR at baseline was 40.2 (IQR, 29.1-54.5) $\mathrm{ml} / \mathrm{min}$. Baseline fasting urine osmolality (Uosm) ranged from 109 to $1114 \mathrm{mOsm} / \mathrm{kg} \mathrm{H}_{2} \mathrm{O}$, with a mean of $502.7 \pm 151.7$ and a median of 482 (IQR, 401.5-591) mOsm $/ \mathrm{kg} \mathrm{H}_{2} \mathrm{O}$. As expected, mean fasting Uosm value was significantly higher in men than women, $514.7 \pm 150.4$ and $477.5 \pm 151.5$, respectively ( $\mathrm{p}<0.001$ ), justifying the use of gender-specific thresholds. Baseline fasting Uosm was positively associated with baseline mGFR in men and women 
(Figure 2).

Patients in the lowest fasting Uosm tertile were older, with a higher prevalence of hypertension $(\mathrm{p}=0.01)$, diabetic nephropathy, polycystic kidney disease, and tubulointerstitial nephropathy $(\mathrm{p}<0.001)$. They also experienced lower fasting urinary ammonium, higher 24-hour urine output, and higher ACR and PCR $(\mathrm{p}<0.001)$. They were more likely to receive anti-proteinuric treatments $(\mathrm{p}=0.01)$ and loop diuretics $(\mathrm{p}<0.001)$. Of note, there was no difference according to fasting Uosm tertiles for natremia.

\section{Hazard ratios for ESRD and death according to fasting Uosm}

Over a median follow-up of 5.9 [IQR, 3.7-8.2] years, there were 380 ESRD events and 225 deaths before ESRD. Crude and adjusted HRs for ESRD were significantly higher in patients with lower baseline fasting Uosm (with adjusted HRs of 1.97 (95\% CI, 1.26-3.08) and 1.18 (95\% CI, 1.06-1.32) for the lowest vs highest tertile and per 100 mOsm/ $\mathrm{kg} \mathrm{H}_{2} \mathrm{O}$ lower baseline Uosm, respectively; table 2). The increased risk of ESRD for low values of osmolality depended neither on the type of nephropathy nor on the age at baseline (interaction p-value $=0.4$ and 0.3 respectively). Additional adjustment for urinary ammonium did not change the association (HRs of 1.91 (95\% CI, 1.18-3.09) and 1.17 (95\% CI, 1.03-1.33) for the lowest vs highest tertile or per $100 \mathrm{mosm} / \mathrm{kg} \mathrm{H}_{2} \mathrm{O}$ lower baseline Uosm, respectively).

Crude HRs for pre-ESRD death were significantly higher in patients with lower baseline fasting Uosm (HRs of 1.42 (95\% CI, 1.03-1.96) and 1.13 (95\% CI, 1.04-1.24) for the lowest vs highest tertile and per $100 \mathrm{mOsm} / \mathrm{kg} \mathrm{H}_{2} \mathrm{O}$ lower baseline Uosm, respectively). Results from sensitivity analyses showed that simple and multiple 
imputations provided very similar HRs for ESRD: adjusted HRs of 1.94 (95\% CI, 1.233.06) and 1.62 (95\% CI, 1.04-2.52) for tertiles 1 and 2, respectively, vs tertile 3; and an HR of 1.20 (95\% CI, 1.06-1.35) per $100 \mathrm{mOsm} / \mathrm{kg} \mathrm{H} \mathrm{H}_{2} \mathrm{O}$ lower baseline Uosm.

Crude HRs for pre-ESRD death were significantly higher in patients with lower fasting Uosm (with HRs of 1.42 (95\% CI, 1.03-1.96) and 1.13 (95\% CI, 1.04-1.24) for the lowest vs highest tertile and per $100 \mathrm{mOsm} / \mathrm{kg} \mathrm{H}_{2} \mathrm{O}$ lower baseline Uosm, respectively). In contrast, adjusted HRs for pre-ESRD death were not statistically significant before and after adjusting for confounders such as natremia status (with adjusted HRs of 0.99 (95\% CI, 0.68-1.44) or 1.04 (95\% CI, 0.92-1.17) the lowest vs highest tertile and per $100 \mathrm{mOsm} / \mathrm{kg} \mathrm{H}_{2} \mathrm{O}$ lower baseline Uosm, respectively; Table S1).

\section{Fasting Uosm and mGFR decline over the study period}

Mean annual change in mGFR was $-6.1 \% \pm 2.8 \%$; the decline was steeper in patients with lower mGFR at baseline $(-9.4 \% \pm 0.8 \%$ per year for $\mathrm{mGFR}<30 \mathrm{ml} / \mathrm{min}$, $6.7 \% \pm 0.6 \%$ per year for $30-44 \mathrm{ml} / \mathrm{min},-4.5 \% \pm 0.4 \%$ per year for $\geq 45 \mathrm{ml} / \mathrm{min}$ ).

In the mixed model adjusted for baseline mGFR and patient characteristics, each $100 \mathrm{mOsm} / \mathrm{kgH}_{2} \mathrm{O}$ lower fasting Uosm at baseline was associated with an mGFR change of $-1.0 \%$ [IQR, $-1.4 \%$ to $-0.6 \%$ ] per year. Patients with urine osmolality in the lowest tertile had a steeper mGFR decline compared to the highest tertile $(-4.9 \%$ [IQR, $-6.6 \%$ to $-3.2 \%$ ] per year - Table 3). In this analysis PCR (log transformed) was the only other variable significantly associated with GFR decline over time.

\section{Discussion}

Our study demonstrates, in a large prospective CKD cohort, an independent relationship between fasting urine osmolality and GFR decline rate and ESRD outcome. 
Impaired ability to concentrate urine is reported in CKD, especially in pre-ESRD stages, and in experimental models such as 5/6 nephrectomized rats ${ }^{2-4,21-24}$. However, its prevalence is unknown according to CKD stages. Our results show that if we consider a normal fasting Uosm value as being above $600 \mathrm{mosm} / \mathrm{l}$ (Osugi et $\mathrm{al}^{25}$ ), a concentrating defect is encountered in $77 \%$ of our study population: $14 \%, 46 \%, 69 \%, 84 \%$ and $98 \%$ of cases in CKD stage 1, 2, 3a, 3b, and 4 subgroups. This high prevalence was expected as urine concentration depends on corticopapillary osmotic gradient integrity, and aquaporin 2 expression levels within collecting duct principal cells, both of which may be altered by $\mathrm{CKD}^{26}$.

Consistently with previous studies, we found a relationship between gender and urine osmolality. After water deprivation, higher urine osmolality and lower urine output were found in male compared to female rats in an experimental study by Wang et al ${ }^{27}$. Interestingly, this difference faded after gonadectomy. Additionally, human physiologic studies have shown the same difference, independent of sodium intake ${ }^{28}$, in healthy individual as well as in $\mathrm{CKD}^{29}$. Higher plasma vasopressin levels were also found in men $^{30}$. Whether these differences are due to a differential vasopressin release, thirst threshold, or renal response to vasopressin, and the influence of sexual hormones, remains poorly evaluated.

There is conflicting literature regarding the role of vasopressin V2 receptor activation, vasopressin, and vasopressin $\mathrm{V} 2$ receptor antagonism in $\mathrm{CKD}$, and especially in ADPKD. Similar to our study, Hebert et al showed that 24-hour urine output was associated with faster eGFR decline in polycystic patients as well as in other CKD patients ${ }^{9}$. Interestingly, Devuyst et al. reported a defect in the concentrating ability of 
patients with ADPKD before treatment with tolvaptan, a vasopressin V2 receptor antagonist that was recently approved for this indication, and an improved response to the treatment in patients with higher baseline Uosm ${ }^{31}$. In contrast, the link between 24-hour urine osmolality and adverse renal outcome has been described in two other studies in global CKD patients and specifically in polycystic kidney patients, respectively ${ }^{8,32}$. However, while fasting Uosm represents the nearest estimation of the maximal urinary concentration ability, 24-hour osmolality rather depends on salt and protein intakes.

CKD is currently assessed by GFR and albuminuria, which evaluate glomerular function ${ }^{33}$. However chronic kidney failure is characterized by alteration to various degrees of other kidney structures such as tubules ${ }^{34,35}$, interstitium ${ }^{36}$ and peritubular capillaries ${ }^{37,38}$. It should be emphasized that all these structures (namely large ascending limb of Henle, peritubular microcirculation, collecting ducts and interstitial cells) are involved in the onset and maintenance of cortico-papillary osmotic gradient ${ }^{26}$. Of note, previous studies have shown that tubular damage assessed on kidney pathology was more correlated with impaired urine concentration and acidification than glomeruli involvement ${ }^{39,40}$, notably because of the presence of atubular glomeruli ${ }^{41}$. Furthermore, along with interstitial fibrosis and peritubular rarefaction, the former is associated with worst renal outcome ${ }^{42-47}$. Accordingly, for a given GFR, the magnitude of the gradient defect assessed by fasting Uosm should quantify tubular and peritubular capillaries damage, i.e. medullary function. In addition to GFR and ACR, fasting Uosm may thus provide relevant information on kidney injury and its measurement is easy to perform in a routine clinical setting. Interestingly, urine ammonium excretion, which depends both on daily acid intake and tubular function, was previously reported as an independent ESRD 
risk factor ${ }^{48}$. We show here that fasting Uosm prognostic value is independent of urine acid excretion.

The hypothesis of an impaired abnormal vasopressin secretion could also explain low urine concentrating capacity. Indeed, hypothalamic-pituitary axis dysfunction has been reported in $\mathrm{CKD}^{49}$. Alternatively, though not mutually exclusive, excessive vasopressin secretion due to tubule resistance ${ }^{23,50,51}$ has been shown to be deleterious in terms of renal outcome ${ }^{6}$. Our data may thus raise the issue whether increased plasma vasopressin or copeptin (which, since it is co-secreted with vasopressin, could be a surrogate marker for it ${ }^{52}$ ) in $\mathrm{CKD}$ could be an adaptive regulation for water balance due to impaired medulla function. Indeed, fasting Uosm remained of prognostic value independently of natremia levels. Conversely, hyponatremia, a state characterized by an impaired diluting ability of distal and collecting duct cells, did not seem to be associated with worse outcomes (i.e. ESRD or pre-ESRD mortality) in our study. Further investigations are warranted in order to address this hypothesis.

Last, the finding that fasting Uosm was an independent risk factor for ESRD, and not for mortality, strengthens the hypothesis that cortico-papillary gradient evaluation provides kidney-specific information on the magnitude of tubular and microvascular lesions. Conversely, mGFR and albuminuria, which are both reported risk factors for ESRD and cardiovascular mortality may instead measure systemic endothelial dysfunction ${ }^{53}$.

Our study displays limitations. First, the fasting nature of Uosm was based on patient declaration and thus may neither be accurate for some individuals (ie, not reflecting the true maximum urine concentration value). However, the range of Uosm 
throughout the study participants was quiet reasonable. 24-hour urine measurement errors can also introduce a bias in the parameters analyzed in our study, since patients often have confusion about the collection protocol, especially the discard of the first urine but not the last one. Second, fasting Uosm was measured by delta cryoscopy in our study, which is not broadly available. Calculated fasting Uosm (= (Urinary sodium ion + Urinary potassium ion) $* 2+$ Urinary urea +/- Urinary glucose) was not available in our study although it is known to be an accurate estimation of measured osmolality ${ }^{54}$. Our findings can also only be generalized to CKD patients. Studies in the general population are warranted in order to evaluate the association of urine osmolality with renal outcome or mortality. Last, further research might allow evaluating the precise relevance of fasting Uosm in individual patient management, and assessing Uosm thresholds that would be specifically associated with adverse renal outcome.

In conclusion, our study demonstrates that fasting Uosm is associated with GFR decline and ESRD outcome in CKD patients, independent of confounding factors including baseline GFR and albuminuria. It may be a useful tool for medullary protection assessment in patients with CKD.

\section{Supplementary Material}

Table S1. Crude and adjusted HRs for mortality before ESRD according to fasting urinary osmolality.

Supplementary Material Descriptive Text for Online Delivery

Supplementary Table S1 (PDF). Crude and adjusted HRs for mortality before ESRD according to fasting urinary osmolality.

\section{Article Information}

NephroTest Study Group Collaborators: Those who contributed to data collection are Marine Livrozet, Emmanuel Letavernier, Pierre Ronco, and Hafedh Fessi (Hôpital Tenon); Emmanuelle Vidal-Petiot, Eric Daugas, and Caroline du Halgouet (Hôpital Bichat); Renaud de La Faille, Gerard Maruani, Marion Vallet, Laurence NicoletBarousse, Mélanie Roland, and Christian Jacquot (Hôpital Européen G. Pompidou). Authors' Full Names and Academic Degrees: 
Authors' Affiliations:

Address for Correspondence:

Authors' Contributions: design of NephroTest cohort: MF, PH, JPH, FV, ET, JJB, and BS; data collection: NT, MF, PH, JPH; design of study analyses: MM, SW, NT, JPH; performed study: MM, SW; interpretation of results: MM, SW, NT, JPH, BS. Each author contributed important intellectual content during manuscript drafting or revision and accepts accountability for the overall work by ensuring that questions pertaining to the accuracy or integrity of any portion of the work are appropriately investigated and resolved.

Support: The NephroTest cohort study was supported by grants from Inserm GISIreSPAO 8113LS TGIR; French Ministry of Health AOM 09114 and AOM 10245; InsermAO8022LS; Agence de la Biomédecine R08156LL; AURA, and Roche 2009 $152-447 \mathrm{G}$. The funders did not have any role in the study design, collection, analysis and interpretation of data, writing the report, or the decision to submit the report for publication.

Financial Disclosure: The authors declare that they have no relevant financial interests.

Peer Review: Received June 5, 2018. Evaluated by 2 external peer reviewers, with direct editorial input from a Statistics/Methods Editor, an Associate Editor, and the Editor-in-Chief. Accepted in revised form December 1, 2018.

\section{Bibliography}

1. Bankir L, Bouby N, Trinh-Trang-Tan M-M. 2 The role of the kidney in the maintenance of water balance. Baillières Clin Endocrinol Metab. 1989;3(2):249-311. doi:10.1016/S0950-351X(89)80005-9

2. Pedersen EB, Thomsen IM, Lauridsen TG. Abnormal function of the vasopressincyclic-AMP-aquaporin2 axis during urine concentrating and diluting in patients with reduced renal function. A case control study. BMC Nephrol. 2010;11:26. doi:10.1186/1471-2369-11-26

3. Combs S, Berl T. Dysnatremias in patients with kidney disease. Am J Kidney Dis Off J Natl Kidney Found. 2014;63(2):294-303. doi:10.1053/j.ajkd.2013.09.017

4. Conte G, Dal Canton A, Fuiano G, et al. Mechanism of impaired urinary concentration in chronic primary glomerulonephritis. Kidney Int. 1985;27(5):792-798.

5. Bouby N, Bachmann S, Bichet D, Bankir L. Effect of water intake on the progression of chronic renal failure in the 5/6 nephrectomized rat. Am J Physiol. 1990;258(4 Pt 2):F973-979.

6. Bankir L, Bouby N, Ritz E. Vasopressin: a novel target for the prevention and retardation of kidney disease? Nat Rev Nephrol. 2013;9(4):223-239.

doi:10.1038/nrneph.2013.22

7. Clark WF, Sontrop JM, Macnab JJ, et al. Urine volume and change in estimated GFR in a community-based cohort study. Clin J Am Soc Nephrol CJASN. 2011;6(11):2634-2641. doi:10.2215/CJN.01990211

8. Plischke M, Kohl M, Bankir L, et al. Urine osmolarity and risk of dialysis initiation in a chronic kidney disease cohort--a possible titration target? PloS One. 2014;9(3):e93226. doi:10.1371/journal.pone.0093226

9. Hebert LA, Greene T, Levey A, Falkenhain ME, Klahr S. High urine volume and 
low urine osmolality are risk factors for faster progression of renal disease. Am J Kidney Dis Off J Natl Kidney Found. 2003;41(5):962-971.

10. Higashihara E, Nutahara K, Tanbo M, et al. Does increased water intake prevent disease progression in autosomal dominant polycystic kidney disease? Nephrol Dial Transplant Off Publ Eur Dial Transpl Assoc - Eur Ren Assoc. 2014;29(9):1710-1719. doi:10.1093/ndt/gfu093

11. Weber M, Berglund D, Reule S, Jackson S, Matas AJ, Ibrahim HN. Daily fluid intake and outcomes in kidney recipients: post hoc analysis from the randomized ABCAN trial. Clin Transplant. 2015;29(3):261-267. doi:10.1111/ctr.12514 12. Nath KA. Tubulointerstitial Changes as a Major Determinant in the Progression of Renal Damage. Am J Kidney Dis. 1992;20(1):1-17. doi:10.1016/S0272-6386(12)80312-X 13. Hewitson TD, Holt SG, Smith ER. Progression of Tubulointerstitial Fibrosis and the Chronic Kidney Disease Phenotype - Role of Risk Factors and Epigenetics. Front Pharmacol. 2017;8:520. doi:10.3389/fphar.2017.00520

14. Servais A, Meas-Yedid V, Noël LH, et al. Interstitial fibrosis evolution on early sequential screening renal allograft biopsies using quantitative image analysis. Am J Transplant Off J Am Soc Transplant Am Soc Transpl Surg. 2011;11(7):1456-1463. doi:10.1111/j.1600-6143.2011.03594.x

15. Bohle A, Wehrmann M, Bogenschütz O, Batz C, Müller CA, Müller GA. The pathogenesis of chronic renal failure in diabetic nephropathy. Investigation of 488 cases of diabetic glomerulosclerosis. Pathol Res Pract. 1991;187(2-3):251-259.

16. Menn-Josephy H, Lee CS, Nolin A, et al. Renal interstitial fibrosis: an imperfect predictor of kidney disease progression in some patient cohorts. Am J Nephrol. 2016;44(4):289-299. doi:10.1159/000449511

17. Moranne O, Froissart M, Rossert J, et al. Timing of onset of CKD-related metabolic complications. J Am Soc Nephrol JASN. 2009;20(1):164-171.

doi:10.1681/ASN.2008020159

18. Froissart M, Rossert J, Jacquot C, Paillard M, Houillier P. Predictive performance of the modification of diet in renal disease and Cockcroft-Gault equations for estimating renal function. J Am Soc Nephrol JASN. 2005;16(3):763-773.

doi:10.1681/ASN.2004070549

19. Noordzij M, Leffondré K, van Stralen KJ, Zoccali C, Dekker FW, Jager KJ. When do we need competing risks methods for survival analysis in nephrology? Nephrol Dial Transplant Off Publ Eur Dial Transpl Assoc - Eur Ren Assoc. 2013;28(11):2670-2677. doi:10.1093/ndt/gft355

20. Gladitz J. Rubin, Donald B.: Multiple Imputation for Nonresponse in Surveys. John Wiley \& Sons, Chichester - New York - Brisbane - Toronto - Singapore 1987, xxx, 258 S., 6 Abb., £ 30.25, ISSN 0271-6232. Biom J. 1989;31(1):131-132.

doi:10.1002/bimj.4710310118

21. Bricker NS, Dewey RR, Lubowitz H, Stokes J, Kirkensgaard T. OBSERVATIONS ON THE CONCENTRATING AND DILUTING MECHANISMS OF THE DISEASED KIDNEY*. J Clin Invest. 1959;38(3):516-523.

22. Coburn JW, Gonick HC, Rubini ME, Kleeman CR. Studies of Experimental Renal Failure in Dogs. I. Effect of 5/6 Nephrectomy on Concentrating and Diluting Capacity of Residual Nephrons*. J Clin Invest. 1965;44(4):603-614.

23. Teitelbaum I, McGuinness S. Vasopressin resistance in chronic renal failure. 
Evidence for the role of decreased V2 receptor mRNA. J Clin Invest. 1995;96(1):378385. doi:10.1172/JCI118044

24. Suzuki K, Hatano R, Michimata M, et al. Residual urinary concentrating ability and AQP2 expression in a rat model for chronic renal failure. Nephron Physiol. 2005;99(1):p16-22. doi:10.1159/000081798

25. Osugi T, Tatara T, Yada S, Tashiro C. Hydration status after overnight fasting as measured by urine osmolality does not alter the magnitude of hypotension during general anesthesia in low risk patients. Anesth Analg. 2011;112(6):1307-1313.

doi:10.1213/ANE.0b013e3182114df4

26. Sands JM, Layton HE. The Physiology of Urinary Concentration: an Update. Semin Nephrol. 2009;29(3):178-195. doi:10.1016/j.semnephrol.2009.03.008

27. Wang Y, Crofton JT, Miller J, et al. Sex Difference in Urinary Concentrating Ability Of Rats with Water Deprivation. 1996; 270(3 Pt 2):R550-5.

doi:10.1152/ajpregu.1996.270.3.R550

28. Crofton JT, Dustan H, Share L, Brooks DP. Vasopressin secretion in normotensive black and white men and women on normal and low sodium diets. J Endocrinol. 1986;108(2):191-199.

29. Perucca J, Bouby N, Valeix P, Bankir L. Sex difference in urine concentration across differing ages, sodium intake, and level of kidney disease. Am J Physiol-Regul Integr Comp Physiol. 2007;292(2):R700-R705. doi:10.1152/ajpregu.00500.2006

30. Hancock ML, Bichet DG, Eckert GJ, Bankir L, Wagner MA, Pratt JH. Race, sex, and the regulation of urine osmolality: observations made during water deprivation. $A m J$ Physiol Regul Integr Comp Physiol. 2010;299(3):R977-980.

doi:10.1152/ajpregu.00289.2010

31. Devuyst O, Chapman AB, Gansevoort RT, et al. Urine Osmolality, Response to Tolvaptan, and Outcome in Autosomal Dominant Polycystic Kidney Disease: Results from the TEMPO 3:4 Trial. J Am Soc Nephrol JASN. 2017;28(5):1592-1602. doi:10.1681/ASN.2016040448

32. Torres VE, Grantham JJ, Chapman AB, et al. Potentially modifiable factors affecting the progression of autosomal dominant polycystic kidney disease. Clin J Am Soc Nephrol CJASN. 2011;6(3):640-647. doi:10.2215/CJN.03250410

33. Fox CS, Matsushita K, Woodward M, et al. Associations of kidney disease measures with mortality and end-stage renal disease in individuals with and without diabetes: a meta-analysis. Lancet Lond Engl. 2012;380(9854):1662-1673. doi:10.1016/S0140-6736(12)61350-6

34. Schelling JR. Tubular atrophy in the pathogenesis of chronic kidney disease progression. Pediatr Nephrol Berl Ger. 2016;31(5):693-706. doi:10.1007/s00467-0153169-4

35. Venkatachalam MA, Weinberg JM, Kriz W, Bidani AK. Failed Tubule Recovery, AKI-CKD Transition, and Kidney Disease Progression. J Am Soc Nephrol JASN. 2015;26(8):1765-1776. doi:10.1681/ASN.2015010006

36. Zeisberg M, Kalluri R. Physiology of the Renal Interstitium. Clin J Am Soc Nephrol. 2015;10(10):1831-1840. doi:10.2215/CJN.00640114

37. Thomas SE, Anderson S, Gordon KL, Oyama TT, Shankland SJ, Johnson RJ. Tubulointerstitial disease in aging: evidence for underlying peritubular capillary damage, a potential role for renal ischemia. J Am Soc Nephrol JASN. 1998;9(2):231-242. 
38. Kida Y, Tchao BN, Yamaguchi I. Peritubular capillary rarefaction: a new therapeutic target in chronic kidney disease. Pediatr Nephrol Berl Ger. 2014;29(3):333342. doi:10.1007/s00467-013-2430-y

39. Bohle A, Mackensen-Haen S, von Gise H. Significance of tubulointerstitial changes in the renal cortex for the excretory function and concentration ability of the kidney: a morphometric contribution. Am J Nephrol. 1987;7(6):421-433. doi:10.1159/000167514 40. Risdon RA, Sloper JC, De Wardener HE. Relationship between renal function and histological changes found in renal-biopsy specimens from patients with persistent glomerular nephritis. Lancet Lond Engl. 1968;2(7564):363-366.

41. Rodríguez-Iturbe B, Johnson RR, Herrera-Acosta J. Tubulointerstitial damage and progression of renal failure. Kidney Int. 2005;68:S82-S86. doi:10.1111/j.15231755.2005.09915.x

42. Ishii Y, Sawada T, Kubota K, Fuchinoue S, Teraoka S, Shimizu A. Injury and progressive loss of peritubular capillaries in the development of chronic allograft nephropathy. Kidney Int. 2005;67(1):321-332. doi:10.1111/j.1523-1755.2005.00085.x

43. Bohle A, Mackensen-Haen S, Wehrmann M. Significance of postglomerular capillaries in the pathogenesis of chronic renal failure. Kidney Blood Press Res. 1996;19(3-4):191-195. doi:10.1159/000174072

44. Chade AR. Renal vascular structure and rarefaction. Compr Physiol. 2013;3(2):817831. doi:10.1002/cphy.c120012

45. Srivastava A, Palsson R, Kaze AD, et al. The Prognostic Value of Histopathologic Lesions in Native Kidney Biopsy Specimens: Results from the Boston Kidney Biopsy Cohort Study. J Am Soc Nephrol JASN. 2018;29(8):2213-2224.

doi:10.1681/ASN.2017121260

46. Nicholson ML, McCulloch TA, Harper SJ, et al. Early measurement of interstitial fibrosis predicts long-term renal function and graft survival in renal transplantation. $\mathrm{Br} J$ Surg. 1996;83(8):1082-1085.

47. Farris $\mathrm{AB}$, Adams $\mathrm{CD}$, Brousaides N, et al. Morphometric and Visual Evaluation of Fibrosis in Renal Biopsies. J Am Soc Nephrol JASN. 2011;22(1):176-186. doi:10.1681/ASN.2009091005

48. Vallet M, Metzger M, Haymann J-P, et al. Urinary ammonia and long-term outcomes in chronic kidney disease. Kidney Int. 2015;88(1):137-145.

doi:10.1038/ki.2015.52

49. Meuwese CL, Carrero JJ. Chronic kidney disease and hypothalamic-pituitary axis dysfunction: the chicken or the egg? Arch Med Res. 2013;44(8):591-600. doi:10.1016/j.arcmed.2013.10.009

50. Tannen RL, Regal EM, Dunn MJ, Schrier RW. Vasopressin-resistant hyposthenuria in advanced chronic renal disease. $N$ Engl J Med. 1969;280(21):1135-1141. doi:10.1056/NEJM196905222802101

51. Fine LG, Schlondorff D, Trizna W, Gilbert RM, Bricker NS. Functional profile of the isolated uremic nephron. Impaired water permeability and adenylate cyclase responsiveness of the cortical collecting tubule to vasopressin. J Clin Invest. 1978;61(6):1519-1527. doi:10.1172/JCI109072

52. Morgenthaler NG, Struck J, Alonso C, Bergmann A. Assay for the measurement of copeptin, a stable peptide derived from the precursor of vasopressin. Clin Chem. 2006;52(1):112-119. doi:10.1373/clinchem.2005.060038 
53. Chronic Kidney Disease Prognosis Consortium, Matsushita K, van der Velde M, et al. Association of estimated glomerular filtration rate and albuminuria with all-cause and cardiovascular mortality in general population cohorts: a collaborative meta-analysis.

Lancet Lond Engl. 2010;375(9731):2073-2081. doi:10.1016/S0140-6736(10)60674-5

54. Penney MD, Walters G. Are osmolality measurements clinically useful? Ann Clin

Biochem. 1987;24 ( Pt 6):566-571. doi:10.1177/000456328702400603 
Table 1. Patients characteristics according to baseline urinary osmolality

\begin{tabular}{|c|c|c|c|c|c|c|}
\hline & \multirow{2}{*}{$\begin{array}{l}\text { Overall*}^{*} \\
(n=1796)\end{array}$} & \multicolumn{3}{|c|}{ Baseline fasting urinary osmolality } & \multirow[b]{2}{*}{ p-value } & \multirow[b]{2}{*}{ Missing data } \\
\hline & & $\begin{array}{l}\text { Tertile1 } \\
\text { (low; } n=594)\end{array}$ & $\begin{array}{l}\text { Tertile2 } \\
\text { (medium; } \mathrm{n}=598 \text { ) }\end{array}$ & $\begin{array}{l}\text { Tertile3 } \\
\text { (high; } \mathrm{n}=604 \text { ) }\end{array}$ & & \\
\hline Age $(y)$ & $58.7 \pm 15.2$ & $58.0 \pm 15.8$ & $60.4 \pm 14.4$ & $57.7 \pm 15.2$ & 0.01 & 0 \\
\hline Male sex & $67.7(1216)$ & $67.7(402)$ & $67.7(398)$ & $67.8(416)$ & 0.9 & 0 \\
\hline African American & $12.7(228)$ & $12.0(71)$ & $11.9(70)$ & $14.2(87)$ & 0.7 & 82 \\
\hline $\mathrm{BMI}\left(\mathrm{kg} / \mathrm{m}^{2}\right)$ & $26.6 \pm 5.1$ & $26.4 \pm 5.2$ & $26.7 \pm 5.0$ & $26.6 \pm 5.1$ & 0.5 & 0 \\
\hline Former smokers & $32.5(583)$ & $31.0(184)$ & $33.8(199)$ & $32.6(200)$ & 0.8 & 0 \\
\hline Current smokers & $14.1(253)$ & $15.2(90)$ & $13.3(78)$ & $13.8(85)$ & & 0 \\
\hline Diabetes & $27.3(490)$ & $27.1(161)$ & $30.3(178)$ & $24.6(151)$ & 0.1 & 0 \\
\hline Hypertension & $91.4(1641)$ & $92.6(550)$ & $93.0(547)$ & $88.6(544)$ & 0.01 & 0 \\
\hline CV history & $18.2(326)$ & $20.2(120)$ & $18.7(110)$ & $15.6(96)$ & 0.2 & 36 \\
\hline Type of nephropathy & & & & & $<0.001$ & 0 \\
\hline Diabetic & $10.1(181)$ & $10.9(65)$ & $12.2(72)$ & $7.2(44)$ & & \\
\hline Glomerular & $14.5(260)$ & $14.8(88)$ & $14.3(84)$ & $14.3(88)$ & & \\
\hline Vascular & $26.6(477)$ & $23.9(142)$ & $28.7(169)$ & $27.0(166)$ & & \\
\hline Polycystic & $5.8(105)$ & $7.4(44)$ & $6.1(36)$ & $4.1(25)$ & & \\
\hline Tubulo-interstitial & $9.2(166)$ & $13.6(81)$ & $7.8(46)$ & $6.4(39)$ & & \\
\hline Others & $33.8(607)$ & $29.3(174)$ & $30.8(181)$ & $41.0(252)$ & & \\
\hline mGFR (ml/min) & $40.2(29.1-54.5)$ & $30.7(22.9-43.1)$ & $36.5(28.6-48.0)$ & $53.7(42.0-68.1)$ & $<0.001$ & 0 \\
\hline CKD stage & & & & & $<0.001$ & \\
\hline orocongu & $2.1(37)$ & $0.5(3)$ & $0.3(2)$ & $5.2(32)$ & & \\
\hline 2 & $16.7(300)$ & $6.9(41)$ & $9.5(56)$ & $33.1(203)$ & & \\
\hline $3 a$ & $22.1(396)$ & $15.8(94)$ & $19.7(116)$ & $30.3(186)$ & & \\
\hline $3 b$ & $31.9(572)$ & $28.6(170)$ & $41.8(246)$ & $25.4(156)$ & & \\
\hline 4 & $27.3(491)$ & $48.2(286)$ & $28.6(168)$ & $6.0(37)$ & & \\
\hline Volemia & $21.5(19.6-23.6)$ & $21.6(19.6-23.5)$ & $21.4(19.5-23.7)$ & $21.5(19.7-23.6)$ & 0.9 & 232 \\
\hline $\mathrm{ACR}(\mathrm{mg} / \mathrm{mmol})$ & $8.0(1.5-47.2)$ & $18.7(3.5-96.9)$ & $11.7(1.8-57.3)$ & $3.0(0.8-14.2)$ & $<0.001$ & 52 \\
\hline Albuminuria & & & & & & 52 \\
\hline Normal to mildly increased (<3 mg/mmol) & $35.1(612)$ & $22.4(133)$ & $29.3(172)$ & $49.8(306)$ & $<0.001$ & 52 \\
\hline Moderately increased $(3-30 \mathrm{mg} / \mathrm{mmol})$ & $32.3(580)$ & $31.1(185)$ & $33.7(198)$ & $32.1(197)$ & & \\
\hline Severely increased $(\geq 30 \mathrm{mg} / \mathrm{mmol})$ & $30.8(553)$ & $43.4(258)$ & $33.5(197)$ & $16.0(98)$ & & \\
\hline PCR $(\mathrm{mg} / \mathrm{mmol})$ & $25.9(11.6-89.3)$ & $52.3(17.9-165.2)$ & $32.4(13.3-103.9)$ & $14.7(8.2-34.6)$ & $<0.001$ & 83 \\
\hline $24 \mathrm{~h}$ urinary output $(\mathrm{l} / 24 \mathrm{~h})$ & $2.0(1.5-2.5)$ & $2.3(1.8-2.9)$ & $2.0(1.5-2)$. & $1.7(1.4-2.2)$ & $<0.001$ & 67 \\
\hline Fasting urinary ammonium $(\mathrm{mmol} / \mathrm{l})$ & $12.5(7.6-21.0)$ & $7.5(4.6-10.9)$ & $12.9(9.2-18.7)$ & $23.4(15.5-32.0)$ & $<0.001$ & 445 \\
\hline Protein intake $(\mathrm{g} / \mathrm{kg} / \mathrm{d})$ & $1.0(0.9-1.2)$ & $1.0(0.9-1.2)$ & $1.1(0.9-1.2)$ & $1.0(0.9-1.2)$ & 0.4 & 241 \\
\hline Loop diuretics & $28.4(510)$ & $33.7(200)$ & $32.8(193)$ & $19.1(117)$ & $<0.001$ & 1 \\
\hline Thiazide diuretics & $20.4(366)$ & $17.3(103)$ & $22.8(134)$ & $21.0(129)$ & 0.06 & 1 \\
\hline
\end{tabular}


Categorical data expressed as count (percentage); continuous data as mean \pm SD or median [interquartile range] as appropriate.

BMI: body mass index, CV: cardiovascular, mGFR: measured glomerular filtration rate, ACR: albumin-creatinine ratio, PCR: protein-creatinine ratio, ACEi:

angiotensin converting enzyme inhibitor, ARB: angiotensin receptor blocker.

* Fasting urine osmolality 482 (IQR, 401-591) $\mathrm{mOsm} / \mathrm{kg} \mathrm{H} \mathrm{H}_{2} \mathrm{O}$

Tertiles were gender-specific: T1 (low): 109-444 mOsm $/ \mathrm{kg} \mathrm{H}_{2} \mathrm{O}$ for men, $121-402 \mathrm{mOsm} / \mathrm{kg} \mathrm{H}_{2} \mathrm{O}$ for women, T2 (medium): $445-557 \mathrm{mOsm} / \mathrm{kg} \mathrm{H} \mathrm{H}_{2} \mathrm{O}$ for men, $403-$

$516 \mathrm{mOsm} / \mathrm{kg} \mathrm{H} \mathrm{H}_{2} \mathrm{O}$ for women, T3 (high): 558-1114 mOsm $/ \mathrm{kg} \mathrm{H} \mathrm{H}_{2} \mathrm{O}$ for men, $517-1031 \mathrm{mOsm} / \mathrm{kgH}_{2} \mathrm{O}$ for women. 
Table 2. Crude and adjusted hazard ratios for ESRD according to fasting urinary osmolality.

\begin{tabular}{|c|c|c|c|c|c|c|c|}
\hline & \multirow{2}{*}{$\begin{array}{l}\text { Per } 100- \\
\mathrm{mOsm} / \mathrm{kgH}_{2} \mathrm{O} \text { lower } \\
\text { baseline fasting } \\
\text { urinary osmolality } \\
\end{array}$} & \multirow{2}{*}{ p-value } & \multicolumn{3}{|c|}{ baseline fasting urinary osmolality } & \multirow{2}{*}{$\begin{array}{l}p \text {-wald } \\
\text { test }\end{array}$} & \multirow{2}{*}{$\begin{array}{l}\mathrm{p} \\
\text { for trend }\end{array}$} \\
\hline & & & $\begin{array}{l}\text { Tertile1 } \\
\text { (low) }\end{array}$ & $\begin{array}{l}\text { Tertile2 } \\
\text { (medium) }\end{array}$ & $\begin{array}{l}\text { Tertile3 } \\
\text { (high) }\end{array}$ & & \\
\hline $\begin{array}{l}\text { No. of events/no. } \\
\text { at risk }\end{array}$ & $380 / 1796$ & & $223 / 594$ & $131 / 588$ & $26 / 614$ & & \\
\hline Crude Model & \begin{tabular}{|l|}
1.67 \\
$(1.54-1.80)$
\end{tabular} & $<0.001$ & $\begin{array}{l}10.65 \\
(7.09-15.99)\end{array}$ & $\begin{array}{l}5.43 \\
(3.57-8.27)\end{array}$ & 1.00 (reference) & $<0.001$ & $<0.001$ \\
\hline Model 1 & $\begin{array}{l}1.28 \\
(1.15-1.41)\end{array}$ & $<0.001$ & $\begin{array}{l}3.03 \\
(1.97-4.66)\end{array}$ & $\begin{array}{l}2.15 \\
(1.40-3.32)\end{array}$ & 1.00 (reference) & $<0.001$ & $<0.001$ \\
\hline Model 2 & $\begin{array}{l}1.26 \\
(1.14-1.40)\end{array}$ & $<0.001$ & $\begin{array}{l}2.68 \\
(1.73-4.14)\end{array}$ & $\begin{array}{l}2.05 \\
(1.33-3.17)\end{array}$ & 1.00 (reference) & $<0.001$ & $<0.001$ \\
\hline Model 3 & $\begin{array}{l}1.18 \\
(1.06-1.32)\end{array}$ & 0.004 & $\begin{array}{l}1.97 \\
(1.26-3.08)\end{array}$ & $\begin{array}{l}1.62 \\
(1.04-2.52)\end{array}$ & 1.00 (reference) & 0.01 & 0.003 \\
\hline
\end{tabular}

Unless otherwise indicated, values shown are hazard ratios (95\% confidence interval).

Model 1: adjusted for mGFR with time-depending effect

Model 2: Model $1+$ age, gender, centre, ethnicity, obesity

Model 3: Model $2+$ ACR category (<3, 3-30, $>30 \mathrm{mg} / \mathrm{mmol})$, high blood pressure, diabetes, CV history, smoking status, ACEi or ARBs, nephropathy type and

natremia

Tertiles were gender-specific: $\mathrm{T} 1$ (low): $109-444 \mathrm{mOsm} / \mathrm{kgH}_{2} \mathrm{O}$ for men, $121-402 \mathrm{mOsm} / \mathrm{kgH}_{2} \mathrm{O}$ for women, $\mathrm{T2}$ (medium): $445-557 \mathrm{mOsm} / \mathrm{kgH} \mathrm{H}_{2} \mathrm{O}$ for men, $403-516$ $\mathrm{mOsm} / \mathrm{kgH}_{2} \mathrm{O}$ for women, T3 (high): 558-1114 mOsm $/ \mathrm{kg} \mathrm{H}_{2} \mathrm{O}$ for men, $517-1031 \mathrm{mOsm} / \mathrm{kgH}_{2} \mathrm{O}$ for women. 
Table 3. Linear mixed model analysis of the mean effect of fasting urinary osmolality at baseline on change over time of mGFR decline

\begin{tabular}{|l|l|l|l|l|l|}
\hline & $\begin{array}{l}\text { Per 100-mOsm/ } \mathrm{kgH}_{2} \mathrm{O} \text { lower } \\
\text { baseline fasting urinary osmolality }\end{array}$ & $\mathrm{p}$-value & $\begin{array}{l}\text { baseline fasting urinary osmolality } \\
\text { (low) }\end{array}$ & $\begin{array}{l}\text { Tertile2 } \\
\text { (medium) }\end{array}$ \\
\hline Model 1 & $-1.4 \%(-1.8 \%$ to $-0.9 \%)$ & $<0.001$ & $-4.9 \%(-6.6 \%$ to $-3.2 \%)$ & $-2.1 \%(-3.4 \%$ to $-0.9 \%)$ & $<0.001$ \\
\hline Model 2 & $-1.0 \%(-1.4 \%$ to $-0.6 \%)$ & $<0.001$ & $-4.9 \%(-6.6 \%$ to $-3.2 \%)$ & $-2.2 \%(-3.4 \%$ to $-0.9 \%)$ & $<0.001$ \\
\hline
\end{tabular}

Values shown are mean difference in mGFR slope [95\% Cl], expressed as percent per year

*Tertile 3 (high baseline fasting osmolality) is the reference group ( 0 change).

Model 1: includes intercept, time, fasting urinary osmolality at baseline, GFR group and an interaction between time and fasting urinary osmolality at baseline.

Model 2: includes Model 1 variables and mean effect on $\log (\mathrm{PCR})$ slope and mean effect on GFR at baseline of the following covariates: age, gender, centre, ethnicity, diabetes, elevated blood pressure, BMI, cardiovascular history, smoking, and $\log (\mathrm{PCR})$. Interaction terms between covariates and time, except $\log (\mathrm{PCR})$ were non-significant and were not included in the final model.

Tertiles were gender-specific: T1 (low): $109-444 \mathrm{mOsm} / \mathrm{kgH}_{2} \mathrm{O}$ for men, $121-402 \mathrm{mOsm} / \mathrm{kgH}_{2} \mathrm{O}$ for women, T2 (medium): $445-557 \mathrm{mOsm} / \mathrm{kg} \mathrm{H}_{2} \mathrm{O}$ for men, $403-516 \mathrm{mOsm} / \mathrm{kg} \mathrm{H}_{2} \mathrm{O}$ for women, $\mathrm{T} 3$ (high): $558-1114 \mathrm{mOsm} / \mathrm{kgH}_{2} \mathrm{O}$ for men, 517-1031 mOsm $/ \mathrm{kg} \mathrm{H}_{2} \mathrm{O}$ for women 


\section{Figures}

Figure 1. Study Flowchart. mGFR: measured glomerular filtration rate.

Figure 2. Baseline Fasting Uosm according to baseline CKD stages in men and women. mGFR: measured glomerular filtration rate. 


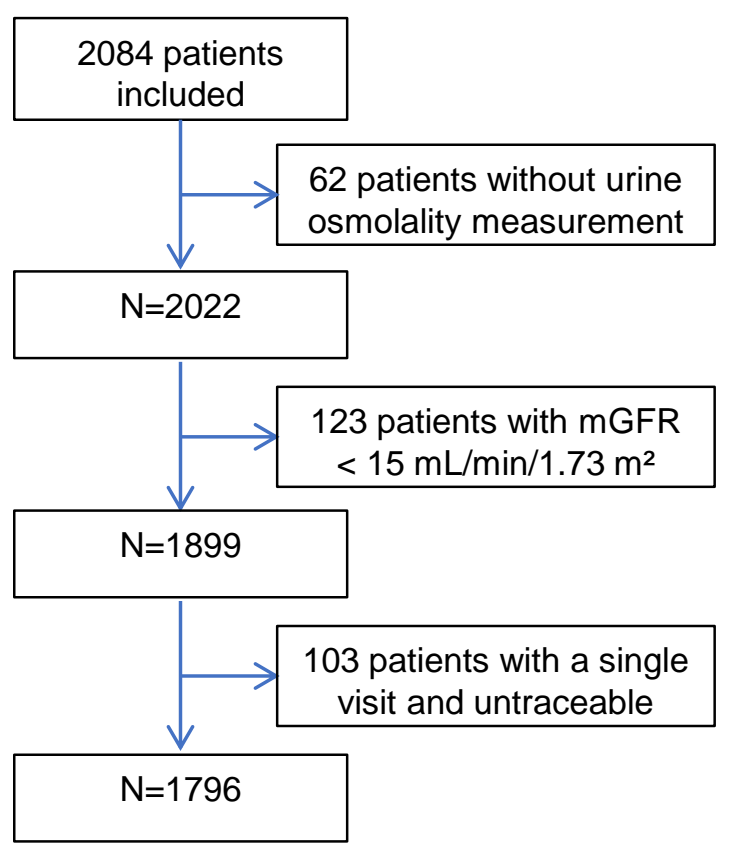




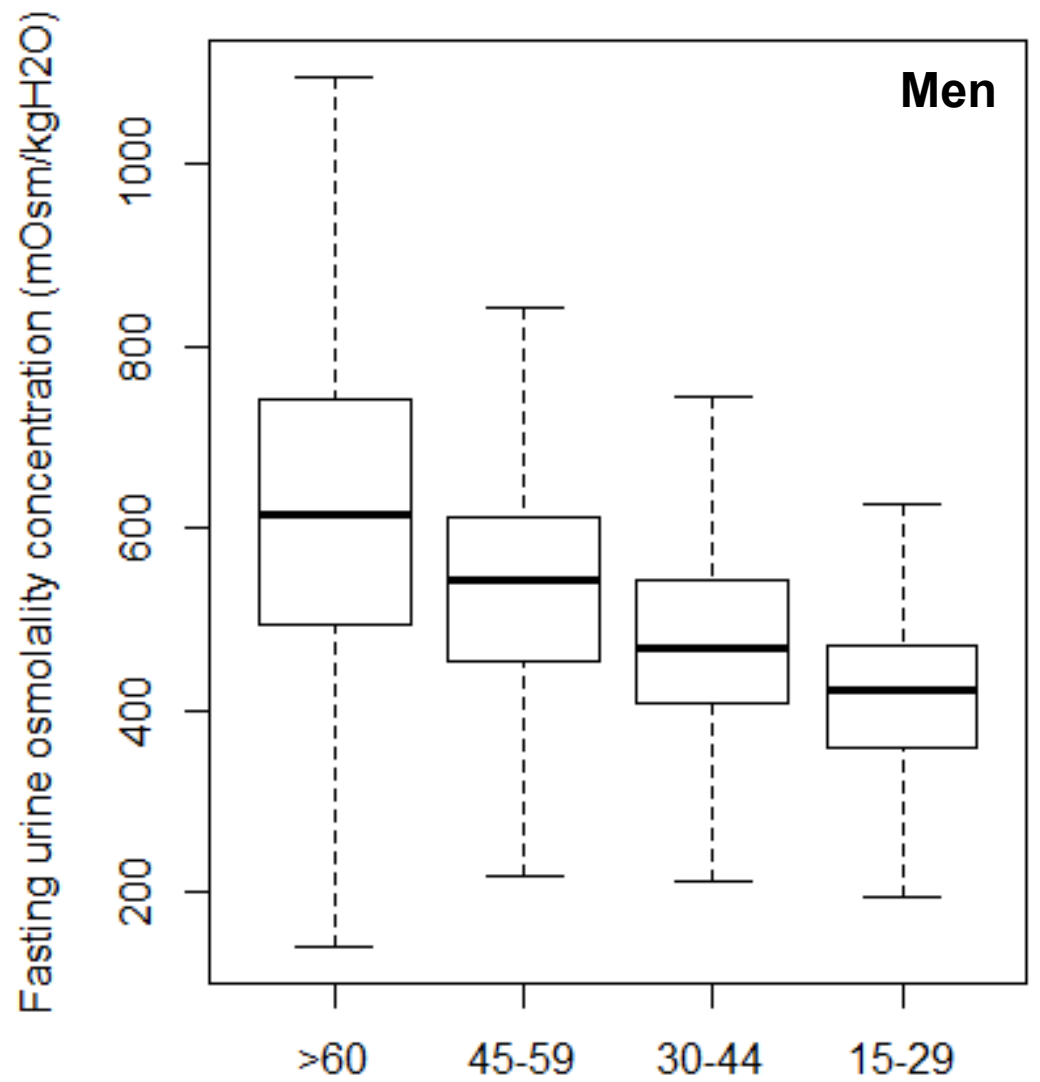

Baseline mGFR $\left(\mathrm{mL} / \mathrm{min} / 1.73 \mathrm{~m}^{2}\right)$

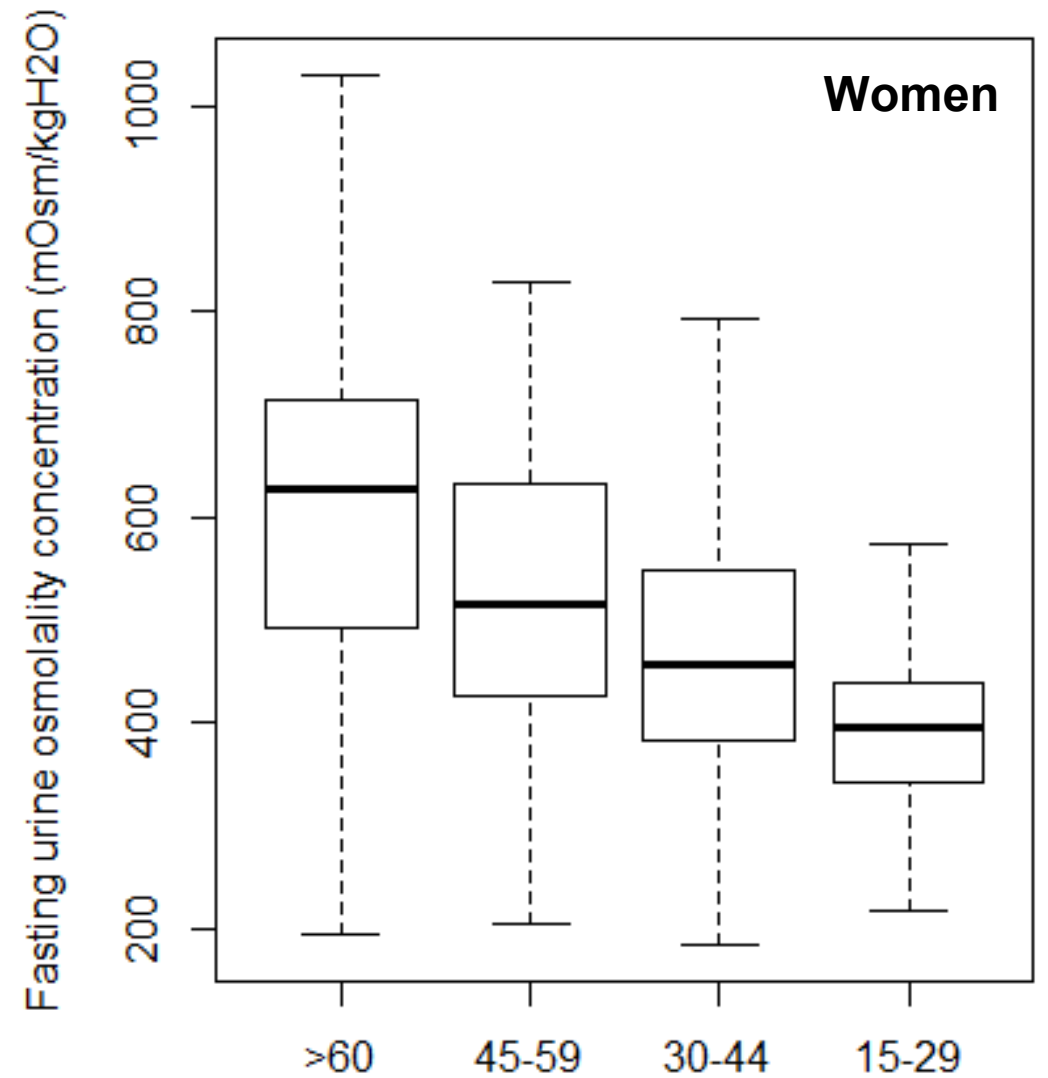

Baseline mGFR (mL/min/1.73m²) 